\title{
Similarity, Pattern, and Grouping of Soybean Fungal Diseases in the United States: Implications for the Risk of Soybean Rust
}

\author{
X. Li and X. B. Yang, Department of Plant Pathology, Iowa State University, Ames, IA 50011
}

\begin{abstract}
Li, X., and Yang, X. B. 2009. Similarity, pattern, and grouping of soybean fungal diseases in the United States: Implications for the risk of soybean rust. Plant Dis. 93:162-169.

Ten biological or ecological characteristics of pathogens/diseases were used to quantitatively describe 34 soybean (Glycine max) fungal diseases in the United States. These characteristics included optimal temperatures for disease development, host ranges, characteristics of disease cycle, and the pathogens' survival capacity. Gower's general similarity coefficients for pairs of diseases were determined and used in principal coordinate analysis (PCoA) to project the diseases into a two-dimensional space, in which significant patterns were identified for some of the characteristic variables, e.g., means of pathogen dispersal. Similarity coefficients indicated that soybean rust (Phakopsora pachyrhizi) resembled soybean downy mildew (Peronospora manshurica) and Leptosphaerulina leaf spot (Leptosphaerulina trifolii). Cluster analysis with multiscale bootstrapping identified two major clusters with high significance level $(P>0.95)$. In a loose cluster $(P=0.86)$, soybean rust was grouped with brown spot (Septoria glycines), frogeye leaf spot (Cercospora sojina), Phyllosticta leaf spot (Phyllosticta sojicola), purple seed stain (Cercospora kikuchii), downy mildew, and Leptosphaerulina leaf spot. Estimated soybean yield losses in the United States from 1996 to 2005 and the geographical distribution information of the diseases in this cluster implied that the potential geographical distribution range of soybean rust may include most U.S. soybean production regions and that yield losses would be light in the north but moderate in the south if environmental conditions are conducive.
\end{abstract}

Additional keywords: comparative epidemiology, risk assessment

Soybean rust caused by Phakopsora pachyrhizi Sydow entered the continental United States in November 2004 (55). By November 2007, the disease had been reported in states from the Gulf Coast to Iowa (37). As a destructive disease, soybean rust had drawn the attention of plant pathologists for its possible adverse impact on the U.S. soybean (Glycine max (L.) Merr.) industry long before it reached this continent $(33,71)$. Risk assessment of a threatening disease in new geographic regions is challenging when limited information of the disease is available $(70,72)$. In the case of soybean rust, two questions are yet to be answered: (i) Would its potential geographical range cover the main soybean production area in the North Central region? and (ii) How likely is it that soybean rust outbreaks in the United States would cause severe yield losses? Longterm observational data of soybean rust occurrence in the United States could answer these questions, but they are not

Corresponding author: X. B. Yang

E-mail: xbyang@iastate.edu

Co-corresponding author: X. Li

E-mail: Linuslee@iastate.edu

Accepted for publication 16 October 2008.

doi:10.1094/PDIS-93-2-0162

(C) 2009 The American Phytopathological Society available. Thus, alternative sources of information are needed.

In a large agricultural system, there may be many plant diseases, and often many fungal diseases. Diseases may share similar or even identical characteristics, such as temperature ranges for disease development and means of inoculum dissemination. Plant pathologists have employed various approaches in comparative epidemiology to compare different diseases or disease progressions based on quantified similarity coefficients, which indicate how similar the diseases are to each other $(3,30-32,46)$. Comparisons can lead to further classification of different diseases into groups using cluster analysis based on their similarity. Cluster analysis is widely used in biological research to classify objects based on their characteristics or attributes $(24,36)$. In plant pathology, Kranz first employed cluster analysis to examine epidemic patterns of 40 diseases based on 10 quantitative attributes of their disease progress curves (31). Cluster analysis was also used for the detection of genetic similarity of fungal pathogens and their geographical zoning $(35,48)$. Sache and De Vallavieille-Pope used cluster analysis to group 24 airborne diseases such as powdery mildew and rust diseases in several crops based on their biological characteristics (51).

On the other hand, similarities among different diseases/pathogens may result in patterns in regard to but not limited to their spatial or temporal distribution; e.g., cool temperature diseases may tend to occur in the northern United States, while warm temperature diseases may be seen more often in the south. Regional or global patterns of species, such as latitudinal gradients in species richness, species-energy relationships, and species-area curves, have been studied as ecological features of an ecosystem $(8,15,21,39)$. In plant pathology, Yang and Feng (72) found that geographical distribution (defined as disease range) of soybean fungal diseases in North America follows certain patterns (50). Not limited to spatial dimension, other patterns such as temporal patterns may exist $(73,74)$. With similarities and patterns identified, some diseases that are already well documented may provide valuable information for the management of similar diseases. For diseases where risk assessment is necessary, but for which there is limited information, such similarities and patterns among various diseases would also help to bridge the gap of missing information.

Since many soybean fungal diseases have been established in the United States for decades or longer, by using appropriate comparative epidemiologic approaches, we can examine their similarities based on their attributes (30-32,36), which establishes a link among these diseases. We can also examine whether patterns are associated with certain aspects of these diseases, such as regional prevalence, yield losses, and pathogen dispersal. Then, using similarity and the information of the patterns, we may assess unknown aspects of soybean rust in its risk assessment. In this study, the objectives were the following: (i) to examine similarities among soybean fungal diseases in the United States based on their biological and ecological characteristics; and (ii) to examine possible biological, ecological, or geographical patterns among these diseases using classification approaches.

\section{MATERIALS AND METHODS}

Soybean fungal diseases in the United States. More than 30 soybean fungal diseases, including those caused by oomycetes, have been reported in the United States $(9,22,41)$. Some of the diseases are caused by several species, such as Pythium rot with major casual agents including Pythium aphanidermatum, $P$. ultimum, and $P$. irregulare, or by different varieties in 
the same species, such as northern stem canker (Diaporthe phaseolorum var. caulivora) and southern stem canker (D. phaseolorum var. meridionalis) (22). For Rhizoctonia aerial blight, the major causal agent is Rhizoctonia solani anastomosis group 1 (AG1). For Rhizoctonia root rot, the major causal agent is $R$. solani anastomosis group 4 (AG4). All of these major causal agents, including species, varieties, and anastomosis groups, were included separately as long as information was available. Finally, 34 soybean fungal pathogens including varieties and anastomosis groups that cause 32 soybean diseases (Table 1) were included in our analy- sis. Each one of them was assigned a code, based on the disease's common name or the causal pathogens' Latin names if there are multiple causal agents. For instance, soybean rust was coded as SbR; Pythium root rot caused by Pythium irregulare was coded as PyI (see Table 1 for more information).

Besides the real soybean diseases, we designed three virtual diseases, which do not exist in nature. The first one is termed "Average Disease", for which the characteristic values were designated based on the averaged and then rounded-up values of the characteristics of all other real diseases; therefore, it has the most frequently presented biological and ecological characteristics among all the real diseases. The second one is termed "Super Disease", which has the characteristics favorable for disease epidemics and pathogen survival. Determination of what characteristics are favorable for a disease epidemic was based on general biological knowledge and expert estimation. For example, one may postulate that a pathogen would be favored for survival and disease epidemics with characteristics of broad host range, longterm survival without hosts, and multiple means of dispersal (seed, wind, debris, etc). The third designed disease is "Weak Disease", which has characteristics unfa-

Table 1. Disease and pathogen names, disease codes, and variable values of descriptive characteristics of soybean fungal diseases in the United States

\begin{tabular}{|c|c|c|c|c|c|c|c|c|c|c|c|c|c|}
\hline Disease name & Pathogen name & Code & OT $^{\mathbf{a}}$ & $\mathbf{H R}^{\mathrm{b}}$ & $\mathbf{F M}^{\mathbf{c}}$ & IPd $^{d}$ & $\mathbf{G S}^{\mathbf{e}}$ & $\mathbf{S I} \mathbf{f}^{\mathbf{f}}$ & $\mathbf{W D}^{\mathrm{g}}$ & $S T^{h}$ & $\mathbf{S R}^{\mathbf{i}}$ & $\mathbf{L S}^{\mathbf{j}}$ & Data source \\
\hline Alternaria leaf spot & Alternaria alternata & ALS & 25 & 3 & 0 & 1 & 0 & 1 & 1 & 1 & 1 & 0 & $20,22,23,27$ \\
\hline Anthracnose & Colletotrichum truncatum & Anr & 28 & 3 & 0 & 1 & 1 & 1 & 0 & 1 & 1 & 0 & $9,22,25,59$ \\
\hline Brown spot & Septoria glycines & $\mathrm{BrS}$ & 25 & 2 & 1 & 1 & 1 & 1 & 1 & 1 & 1 & 0 & 22 \\
\hline Brown stem rot & Phialophora gregata & BSR & 23 & 2 & 0 & 0 & 1 & 1 & 0 & 1 & 1 & 1 & $9,10,22$ \\
\hline Charcoal rot & Macrophomina phaseolina & ChR & 34 & 3 & 0 & 0 & 0 & 0 & 0 & 1 & 1 & 1 & $2,22,41,42$ \\
\hline Choanephora leaf blight & Choanephora infundibulifera & CLB & 28 & 3 & 1 & 1 & 1 & 1 & 0 & 0 & 1 & 0 & 41 \\
\hline Downy mildew & Peronospora manshurica & DwM & 21 & 1 & 1 & 1 & 1 & 1 & 1 & 1 & 0 & 0 & $9,22,41,69$ \\
\hline Frogeye leaf spot & Cercospora sojina & FLS & 26 & 2 & 1 & 1 & 1 & 1 & 1 & 1 & 1 & 0 & 9,38 \\
\hline Fusarium pod and collar rot & Fusarium pallidoroseum & FPC & 24 & 3 & 0 & 0 & 1 & 0 & 0 & 1 & 1 & 1 & 9,22 \\
\hline Fusarium root rot & Fusarium solani & FRR & 18 & 3 & 0 & 0 & 0 & 0 & 0 & 1 & 1 & 1 & 9,22 \\
\hline Fusarium wilt & $\begin{array}{l}\text { Fusarium oxysporum } \\
\text { f. sp. tracheiphilum }\end{array}$ & FWi & 22 & 2 & 0 & 0 & 1 & 0 & 0 & 1 & 1 & 1 & $9,22,43$ \\
\hline Leptosphaerulina leaf spot & Leptosphaerulina trifolii & LLS & 18 & 2 & 1 & 1 & 1 & 1 & 1 & 0 & 1 & 0 & 6,9 \\
\hline Myrothecium leaf spot & Myrothecium roridum & MLS & 27 & 3 & 0 & 1 & 1 & 1 & 0 & 1 & 1 & 0 & $4,9,34,41$ \\
\hline Neocosmospora stem rot & Neocosmospora vasinfecta & NSR & 27 & 2 & 0 & 0 & 0 & 0 & 0 & 0 & 1 & 1 & $11,22,44$ \\
\hline Northern stem canker & $\begin{array}{l}\text { Diaporthe phaseolorum } \\
\text { var. caulivora }\end{array}$ & NSC & 23 & 3 & 1 & 0 & 1 & 1 & 1 & 1 & 1 & 0 & $22,26,63$ \\
\hline Phomopsis seed decay & Phomopsis longicolla & PSD & 30 & 3 & 1 & 1 & 1 & 1 & 0 & 1 & 1 & 0 & $5,16,22,41$ \\
\hline Phyllosticta leaf spot & Phyllosticta sojicola & PLS & 22 & 1 & 1 & 1 & 1 & 1 & 1 & 1 & 1 & 0 & 9,41 \\
\hline Phytophthora rot & Phytophthora sojae & PpR & 26 & 1 & 1 & 0 & 0 & 1 & 0 & 1 & 0 & 1 & 9,22 \\
\hline Pod and stem blight & $\begin{array}{l}\text { Diaporthe phaseolorum } \\
\text { var. sojae }\end{array}$ & PSB & 25 & 3 & 0 & 0 & 1 & 1 & 0 & 1 & 1 & 0 & $22,28,41,62$ \\
\hline Powdery mildew & Microsphaera diffusa & PwM & 20 & 3 & 0 & 1 & 1 & 1 & 1 & 0 & 0 & 0 & 22 \\
\hline Purple seed stain & Cercospora kikuchii & PSS & 27 & 3 & 1 & 1 & 1 & 1 & 1 & 1 & 1 & 0 & $9,22,56$ \\
\hline Pythium root rot & Pythium aphanidermatum & PyA & 33 & 3 & 1 & 0 & 0 & 0 & 0 & 0 & 1 & 1 & 22 \\
\hline Pythium root rot & Pythium irregulare & PyI & 30 & 3 & 1 & 0 & 0 & 0 & 0 & 0 & 1 & 1 & 9,22 \\
\hline Pythium root rot & Pythium ultimum & PyU & 22 & 3 & 1 & 0 & 0 & 0 & 0 & 0 & 1 & 1 & 22,54 \\
\hline Red crown rot & Cylindrocladium crotalariae & $\mathrm{RCR}$ & 26 & 3 & 0 & 0 & 1 & 0 & 0 & 0 & 1 & 1 & 22,41 \\
\hline Rhizoctonia aerial blight & Rhizoctonia solani $(\mathrm{AG} 1)^{\mathrm{k}}$ & RAB & 28 & 3 & 1 & 1 & 1 & 1 & 0 & 1 & 1 & 1 & $9,22,41,60$ \\
\hline Rhizoctonia root rot & Rhizoctonia solani (AG4) ${ }^{1}$ & RRR & 25 & 3 & 0 & 0 & 1 & 0 & 0 & 1 & 1 & 1 & $13,22,29$ \\
\hline Sclerotinia stem rot & Sclerotinia sclerotiorum & SSR & 22 & 3 & 1 & 0 & 0 & 1 & 1 & 1 & 1 & 1 & $1,9,22$ \\
\hline Southern blight & Sclerotium rolfsii & $\mathrm{SnB}$ & 30 & 3 & 0 & 0 & 1 & 1 & 0 & 1 & 1 & 1 & $7,22,41,49,52$ \\
\hline Southern stem canker & $\begin{array}{l}\text { Diaporthe phaseolorum } \\
\text { var. meridionalis }\end{array}$ & SSC & 31 & 3 & 1 & 0 & 1 & 1 & 1 & 1 & 1 & 0 & 22,47 \\
\hline Soybean rust & Phakopsora pachyrhizi & $\mathrm{SbR}$ & 26 & 2 & 1 & 1 & 1 & 1 & 1 & 0 & 0 & 0 & $22,45,46,71$ \\
\hline Sudden death syndrome & $\begin{array}{l}\text { Fusarium solani } \\
\text { f. sp. glycines }\end{array}$ & SDS & 22 & 3 & 0 & 0 & 1 & 0 & 0 & 0 & 1 & 1 & $22,41,53$ \\
\hline Target spot & Corynespora cassiicola & $\mathrm{TaS}$ & 19 & 3 & 0 & 1 & 0 & 1 & 1 & 1 & 1 & 1 & 22,41 \\
\hline Thielaviopsis root rot & Thielaviopsis basicola & TRR & 24 & 3 & 0 & 0 & 1 & 1 & 0 & 1 & 1 & 1 & $9,19,22,41$ \\
\hline Weak disease & - & $\mathrm{WkD}$ & 25 & 1 & 1 & 0 & 0 & 0 & 0 & 0 & 0 & 0 & - \\
\hline Super disease & - & SuD & 25 & 3 & 0 & 1 & 1 & 1 & 1 & 1 & 1 & 1 & - \\
\hline Average disease & - & AvD & 25 & 3 & 1 & 0 & 1 & 1 & 0 & 1 & 1 & 1 & - \\
\hline
\end{tabular}

a OT: optimal temperature $\left({ }^{\circ} \mathrm{C}\right)$ for disease development.

${ }^{\mathrm{b}}$ HR: host ranges; 1 = hosts in genus Glycine; 2 = hosts in other leguminous plants; 3 = hosts in other families.

c FM: whether free moisture from rainfall or dew is needed to facilitate the pathogen to infect; $1=$ yes, $0=$ no.

${ }^{\mathrm{d}}$ IP: parts of soybean plant that are mostly infected by the pathogen; $1=$ upper stem, leaf, and pod; $0=$ root and lower stem.

e GS: soybean plant growth stage that is most infected by pathogen; $1=$ all stages; $0=$ vegetative stage or reproductive stage.

f SI: whether secondary infections occur; $1=$ yes, $0=$ no.

$\mathrm{g}$ WD: whether the pathogen can be dispersed by wind in the field; $1=$ yes, $0=$ no.

${ }^{\mathrm{h}} \mathrm{ST}$ : whether the pathogen can be dispersed by soybean seed transmission; $1=$ yes, $0=$ no.

i SR: whether the pathogen can survive saprophytically in soybean residue and serve as initial inoculum source for the next growing season; $1=$ yes, $0=$ no.

j LS: whether the pathogen can survive saprophytically in the soil without a host, or can be a parasite to other microbes such as nematodes, or can produce dormancy structures such as sclerotia that can survive for a few years; $1=$ yes, $0=$ no.

k AG1: anastomosis group 1 .

1 AG4: anastomosis group 4. 
vorable for pathogen survival and disease epidemics, in contrast to Super Disease. The optimal disease development temperature for these three virtual diseases was set at $25^{\circ} \mathrm{C}$, which was the averaged value for all real soybean diseases. The three virtual diseases served as markers in our analyses for better understanding the features of each group. Also, because they do not exist in nature, it would be interesting to explore what would be the fundamental biological and ecological reasons for their absence, which may give some clues to the occurrence of other diseases such as soybean rust.

Biological and ecological characteristics of soybean diseases. Characterization of soybean diseases was based on quantified descriptive variables that describe certain biological and ecological attributes of these diseases. No universal criteria are available to characterize a disease by biological or ecological attributes, although Kranz suggested some disease descriptors (30). Generally, a disease can be described according to the disease cycle, the pathogen, and host attributes. In our study, four criteria were set when selecting a biological and ecological characteristic of the disease. (i) It must be a descriptive and intrinsic characteristic of the disease, instead of a functional characteristic. For example, whether or not a pathogen is airborne is intrinsically descriptive, while disease infection rate $r$ is functional, because $r$ is associated with the environment. (ii) It must not change frequently. For example, a pathogen's virulence may change quite frequently although it is an intrinsic biological characteristic. In contrast, the optimal temperature for disease development is a much more constant characteristic. Information in the literature on a frequently changing characteristic may be inconsistent at different historical times, which makes it difficult to quantify. (iii) Its spatial scale must be equal to or larger than the field scale, e.g., the spatial scale of disease gradients within plant rows is too small. (iv) The information must be available and reliable. Some biological characteristics such as the optimal environmental relative humidity for disease development had to be excluded from our analysis due to lack of availability or reliability. Besides the fourth criteria, measurement levels are important in characterization of soybean diseases. Generally, the measurement levels used for variables are (i) binary, including symmetric binary, e.g., yes/no, and asymmetric binary, e.g., red color/other color; (ii) nominal, e.g., yellow/red/green; (iii) ordinal, e.g., 1st/2nd/3rd; (iv) interval, e.g., temperatures; and (v) ratio, e.g., percentage (24). In this study, efforts were made to set the variables of the disease characteristics as binary or nominal variables because quantification of some characteristics as interval or ratio variables may not be reliable, although exclusion of these categories would result in loss of information for our analysis.

According to the biological and ecological soybean attributes, soybean disease cycles, and pathogens, 10 variables were defined to describe the characteristics of these diseases. First was the optimal disease development temperature (OT, interval, ${ }^{\circ} \mathrm{C}$ ), which was defined as the environmental temperature that favors the disease development in soybean plants. Second was the host range (HR, ordinal), which describes the categories of the hosts that are regularly infected by soybean disease pathogens. Because some pathogens can infect hundreds of plant species, the host range was reduced to three levels based on a pathogen's specificity of patho- genicity. The host range was 1 when only soybean (Glycine max) or other species in genus Glycine can be the hosts, 2 when leguminous plants other than soybeans can be the hosts, and 3 when plants from other families can be the hosts. The third variable was the free moisture requirement (FM, binary), which was defined as whether free moisture from rainfall or dew is needed for a pathogen to infect host plants. For example, leaf wetness from dew or rainfall is an important requirement for the development of soybean rust ( $P$. pachyrhizi) infection. The free water in soil is not considered as it almost always presents. The fourth variable was defined as the major infected plant parts (IP, binary), which described the parts of the soybean plant that are the most infected by a pathogen. The value was 1 for the upper stem, leaf, or pod, and 0 for root or lower stem. The fifth was the growth stage of infection (GS, asymmetric binary), which described the soybean growth stages when plants are the most infected by a pathogen. If infections generally occur at any stage, the value was 1 ; if infection occurs mostly in the vegetative stage or reproductive stage, the value was 0 . The sixth variable was the occurrence of secondary infection (SI, binary), defined as whether secondary infections occur, in which yes $=1$, no $=0$. The seventh was wind dispersal (WD, asymmetric binary), defined as whether the pathogen dispersal units can be dispersed by wind in the field, in which yes $=1$, no $=$ 0 . The eighth was seed transmittable (ST, binary), defined as whether the pathogen can be dispersed by transmission of soybean seeds, in which yes $=1$, no $=0$. It must be noted that some pathogens that can infect soybean seeds are not seed transmittable. The ninth variable was the survival in host residue (SR, binary), de-

Table 2. Gower's general similarity coefficients for soybean fungal diseases in the United States: Sixteen similarity coefficients greater than 0.9 and one less than 0.1 are listed in the table ${ }^{a}$

\begin{tabular}{|c|c|c|c|c|c|c|c|c|c|c|c|c|c|}
\hline \multirow[b]{2}{*}{ Code } & \multicolumn{13}{|c|}{ Similarity coefficient } \\
\hline & Anr & BrS & ChR & FLS & FPC & FRR & NSC & PyA & PyI & RCR & RRR & TaS & TRR \\
\hline BSR & - & - & - & - & - & - & - & - & - & - & - & - & 0.938 \\
\hline FLS & - & 0.993 & - & - & - & - & - & - & - & - & - & - & - \\
\hline FWi & - & - & - & - & 0.931 & - & - & - & - & - & 0.924 & - & - \\
\hline MLS & 0.992 & - & - & - & - & - & - & - & - & - & - & - & - \\
\hline PLS & - & 0.924 & - & 0.917 & - & - & - & - & - & - & - & - & - \\
\hline PSS & - & 0.931 & - & 0.938 & - & - & - & - & - & - & - & - & - \\
\hline PyI & - & - & - & - & - & - & - & 0.977 & - & - & - & - & - \\
\hline PyU & - & - & - & - & - & - & - & 0.914 & 0.938 & - & - & - & - \\
\hline RRR & - & - & - & - & 0.993 & - & - & - & - & - & - & - & - \\
\hline SDS & - & - & - & - & - & - & - & - & - & 0.972 & - & - & - \\
\hline $\mathrm{SnB}$ & - & - & - & - & - & - & - & - & - & - & - & - & 0.958 \\
\hline SSC & - & - & - & - & - & - & 0.944 & - & - & - & - & - & - \\
\hline WkD & - & - & - & - & - & - & - & - & - & - & - & 0.069 & - \\
\hline
\end{tabular}

a Anr: Anthracnose (Colletotrichum truncatum); BrS: Brown spot (Septoria glycines); BSR: Brown stem rot spot (Phialophora gregata); ChR: Charcoal rot (Macrophomina phaseolina); FLS: Frogeye leaf spot (Cercospora sojina); FPC: Fusarium pod and collar rot (Fusarium pallidoroseum); FRR: Fusarium root rot (Fusarium solani); FWi: Fusarium wilt (Fusarium oxysporum f. sp. tracheiphilum); MLS: Myrothecium leaf spot (Myrothecium roridum); NSC: Northern stem canker (Diaporthe phaseolorum var. caulivora); PLS: Phyllosticta leaf spot (Phyllosticta sojicola); PSS: Purple seed stain (Cercospora kikuchii); PyA: Pythium root rot (Pythium aphanidermatum); PyI: Pythium root rot (Pythium irregulare); PyU: Pythium root rot (Pythium ultimum); RCR: Red crown rot (Cylindrocladium crotalariae); RRR: Rhizoctonia root rot (Rhizoctonia solani [anastomosis group 4]); SDS: Sudden death syndrome (Fusarium solani f. sp. glycines); SSC: South stem canker (Diaporthe phaseolorum var. meridionalis); TaS: Target spot (Corynespora cassiicola); TRR: Thielaviopsis root rot (Thielaviopsis basicola); WkD: Weak disease. 
fined as whether the pathogen can survive saprophytically in soybean residue after harvest and serve as the initial inoculum source for the next growing season, in which yes $=1$, no $=0$. The tenth and last variable was the long-term survival in soil (LS, asymmetric binary), defined as whether the pathogen can survive saprophytically in the soil without the host, can be found parasitically in other microbes such as nematodes, or can produce longterm dormancy structures such as sclerotia that can survive for a few years, in which yes $=1$, no $=0$. All these characteristic variables and their values are summarized in Table 1.

Similarity coefficients among the diseases, principal coordinate analysis, and disease grouping based on cluster analysis. Similarity coefficient (S) describes how similar two objects are to each other, which makes its complement $(1-\mathrm{S})$ the dissimilarity coefficient (D) $(24,36,40)$. In this study, similarity coefficients between each pair of soybean diseases were determined based on their characteristics in Table 1 using Gower's general coefficient of similarity, which is a scale of 0 to 1 and fits all levels of measurements, i.e., binary, asymmetric binary, interval, etc. $(17,24,36)$.

Principal coordinate analysis (PCoA) was conducted to project each disease into a two-dimensional space as a visualized distribution profile of all diseases in this space, among which we can examine possible patterns (36). In this space, the similarity among all the diseases is reserved, in other words, two diseases stay close if their similarity coefficient is large. Principal coordinate analysis was conducted with SAS (SAS Institute, Cary, NC).

Based on the similarity coefficients among the diseases, hierarchical cluster analysis was conducted using unweighted average clustering (also called the unweighted pair-group method using arithmetic averages, UPGMA) to classify the diseases into various groups $(24,36,40)$. Bootstrapping is a powerful resampling technique in statistical analysis to access statistical accuracy even with a small sample size (12). The cluster analysis was conducted using $\mathrm{R}$ statistic package (The $\mathrm{R}$ Foundation for Statistical Computing), in which a multiscale bootstrapping was carried out by an R package "Pvclust" modified to use Gower's similarity as the input. Pvclust provides an AU (Approximately Unbiased) $P$ value for estimation of significant level of each cluster and standard error (SE) of AU $P$ value, with which the true AU $P$ value is between (AU $-2 * \mathrm{SE}$ ) and $(\mathrm{AU}+2 * \mathrm{SE})(57,61)$. First, only real soybean diseases were subjected to cluster analysis. Then the three virtual diseases were incorporated into the dataset. The total number of replications of the bootstrap resampling was setup at 20,000 after several test runs, which resulted in SE < 0.01 for all clusters with AU greater than
$80 \%$. Grouped diseases are illustrated in dendrograms.

\section{RESULTS}

Similarity coefficients among the soybean diseases. Seventeen similarity coefficients among soybean diseases including the virtual diseases are given in Table 2, in which 16 coefficients are greater than 0.9 and one coefficient is less than 0.1. Due to limited space, other similarity coefficients in the range of 0.1 to 0.9 are not shown. The two maximums were equal to 0.993 , between frogeye leaf spot (FLS) and brown spot $(\mathrm{BrS})$ as well as Rhizoctonia root rot (RRR) and Fusarium pod and collar rot (FPC). The minimum one was 0.069 , between the virtual Weak Disease (WkD) and target spot (TaS). Soybean rust had the maximum similarity coefficient of 0.833 with Leptosphaerulina leaf spot (LLS) and the minimum similarity coefficients of 0.1 with charcoal rot $(\mathrm{ChR})$ and Fusarium root rot (FRR). It is interesting that no diseases were either highly similar ( similarity coefficient $>0.9$ ) to the virtual Super Disease $(\mathrm{SuD})$ or to the Average Disease (AvD). The maximum similarity coefficient between a real disease and the Super Disease was 0.863 for target spot; while for the Average Disease, maximum similarity coefficient was 0.882 between it and Thielaviopsis root rot (TRR). For the Weak Disease, Phytophthora rot (PpR) was the closest one, with a relatively small similarity coefficient of 0.617 .

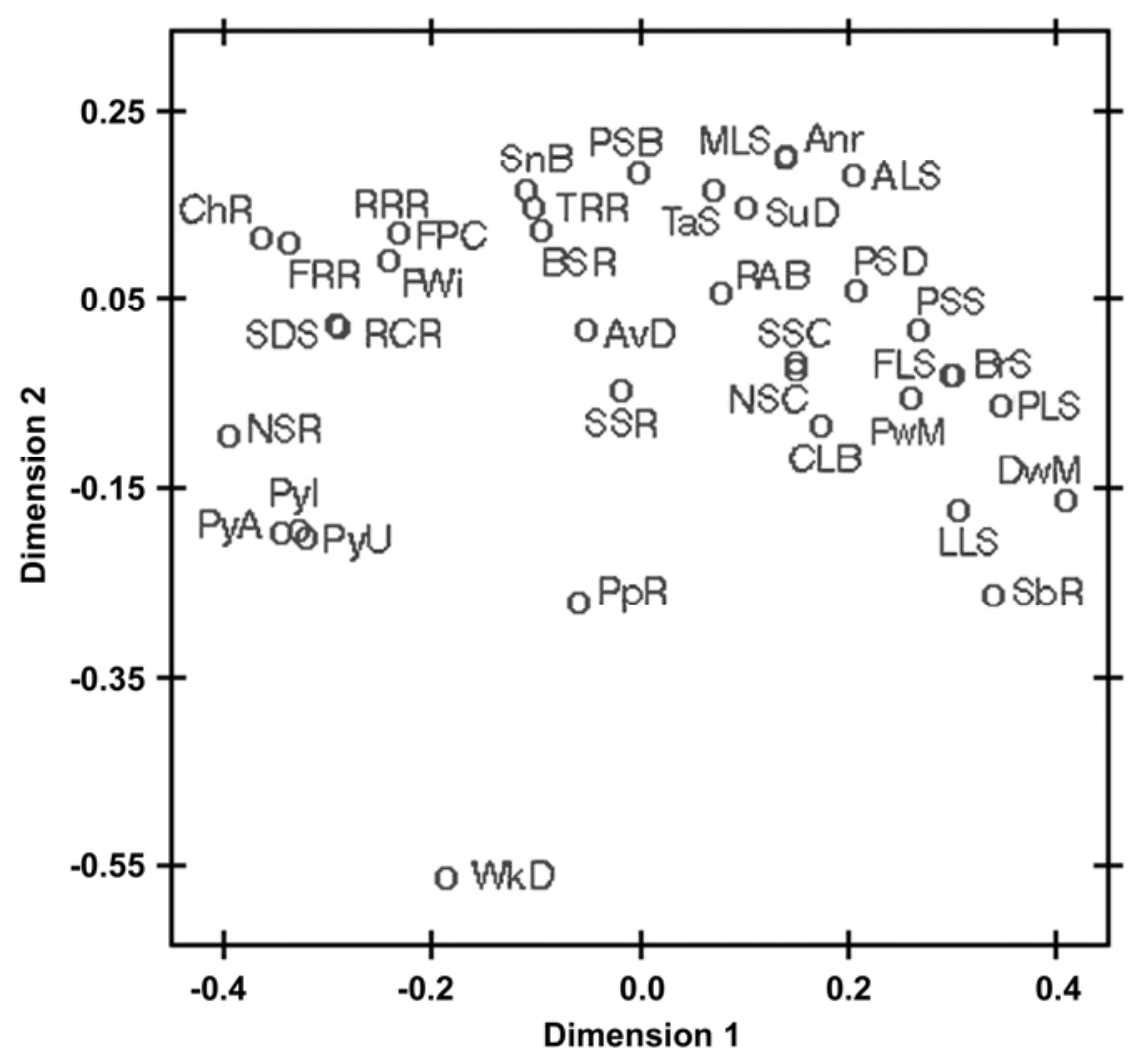

Fig. 1. Projection of all soybean diseases including the three virtual diseases in a two-dimensional space by principal coordinate analysis based on Gower's general similarity coefficients. Open circles represent the diseases, labeled with codes (see Table 1). Circles may overlap due to a large similarity coefficient.
Principal coordinate analysis and projection of the diseases in a twodimensional space. All diseases were nate analysis based on the first and the second dimensions. Eigen values for the first five dimensions were $2.31,1.22,0.59$, 0.46 , and 0.35 , respectively, indicating that the first two dimensions represented most of the variance among the soybean diseases described by the 10 attributes. Soybean rust (SbR) was close to downy mildew (DwM) and Leptosphaerulina leaf spot (LLS), and to several other leaf diseases as well. However, its location was on the lower right side, at the very end of the plot. In contrast, SbR was far away from charcoal rot (ChR) and Fusarium root rot (FRR) in the upper left corner in Figure 1, which reflects their very small similarity coefficients (0.1) with SbR in Table 2. The virtual Average Disease (AvD) was located in the middle of the cloud of all real diseases, which reflects its definition. Super Disease (SuD) was in the upper part of the cloud, close to target spot (TaS). Weak Disease $(\mathrm{WkD})$ was far away from any of these diseases, indicating that its absence in nature is reasonable. At the same time, it is interesting that Phytophthora rot $(\mathrm{PpR})$ also stayed far away from other diseases, although it was much closer to others than Weak Disease.

Different characteristic variables had different distribution patterns in this twodimensional space (Fig. 2A to D). The plotted in Figure 1 using principal coordi- 
general pattern was that most leaf diseases fell on the right side in Figure 1, while the root diseases fell on the left side. A similar pattern was found for the disease attribute of long-term survival (LS) (data not shown in Fig. 1, see Table 1). The attributes of optimal disease development temperature (OT), host range (HR), growth stage of infection (GS), and survival on plant residue (SR) did not show striking patterns (data not shown). Distributions of the other four attributes did show striking and different patterns. In Figure 2A, diseases that need free moisture from rainfall or dew, infections, were located on the lower right side. In Figure 2B, diseases that do not have secondary infections in their disease cycle were located on the left. In Figure $2 \mathrm{C}$, diseases in which pathogens can be wind dispersed in the field were located on the right, mixed with some diseases that are not wind dispersed. In Figure 2D, diseases in which pathogens are not seed transmittable were located on the lower edge of the cloud of projected diseases.

Disease grouping based on cluster analysis. Cluster analysis (UPGMA) results are shown by the dendrograms in Figures 3 and 4. Standard errors were less than 0.01 for all clusters with AU $P$ value greater than $80 \%$ (results not shown). In both dendrograms, two major clusters (Cluster A and B) boxed by dashed lines were identified, which had $P$ value greater i.e., leaf wetness is needed for pathogen

than $95 \%$. Cluster A consisted of brown spot $(\mathrm{BrS})$, frogeye leaf spot (FLS), Phyllosticta leaf spot (PLS), purple seed stain (PSS), and downy mildew (DwM). In both dendrograms, Leptosphaerulina leaf spot (LLS) and soybean rust (SbR) merged with Cluster A to form a bigger but loose cluster (Cluster C) with confidence level only at $86 \%$. Most diseases in this loose cluster were leaf diseases, and they were located in the middle to right part of Figure 1. It is interesting that soybean powdery mildew (PwM) was close to this cluster in Figure 1 but not grouped in it as shown in the dendrograms. In Figure 3, Cluster B consisted of brown stem rot (BSR), southern blight (SnB), Thielaviopsis root rot (TRR), charcoal rot (ChR), Fusarium root rot (FRR), Fusarium pod and collar rot (FPC), Rhizoctonia root rot (RRR), Fusarium wilt (FWi), red crown rot (RCR), and sudden death syndrome (SDS), while in Figure 4, Cluster B consisted of the virtual Average Disease (AvD) in additional to the same diseases in Cluster B in Figure 3. These were all diseases of soybean roots or lower stems, and they were located on the left in Figure 1. For those diseases located in the upper middle part of Figure 1 around the virtual Super Disease, they tended to form small clusters, e.g., anthracnose (Anr) with Myrothecium leaf spot (MLS), Phomopsis seed decay (PSD) with Rhizoctonia aerial blight (RAB), and northern stem canker (NSC) with southern stem canker (SSC).

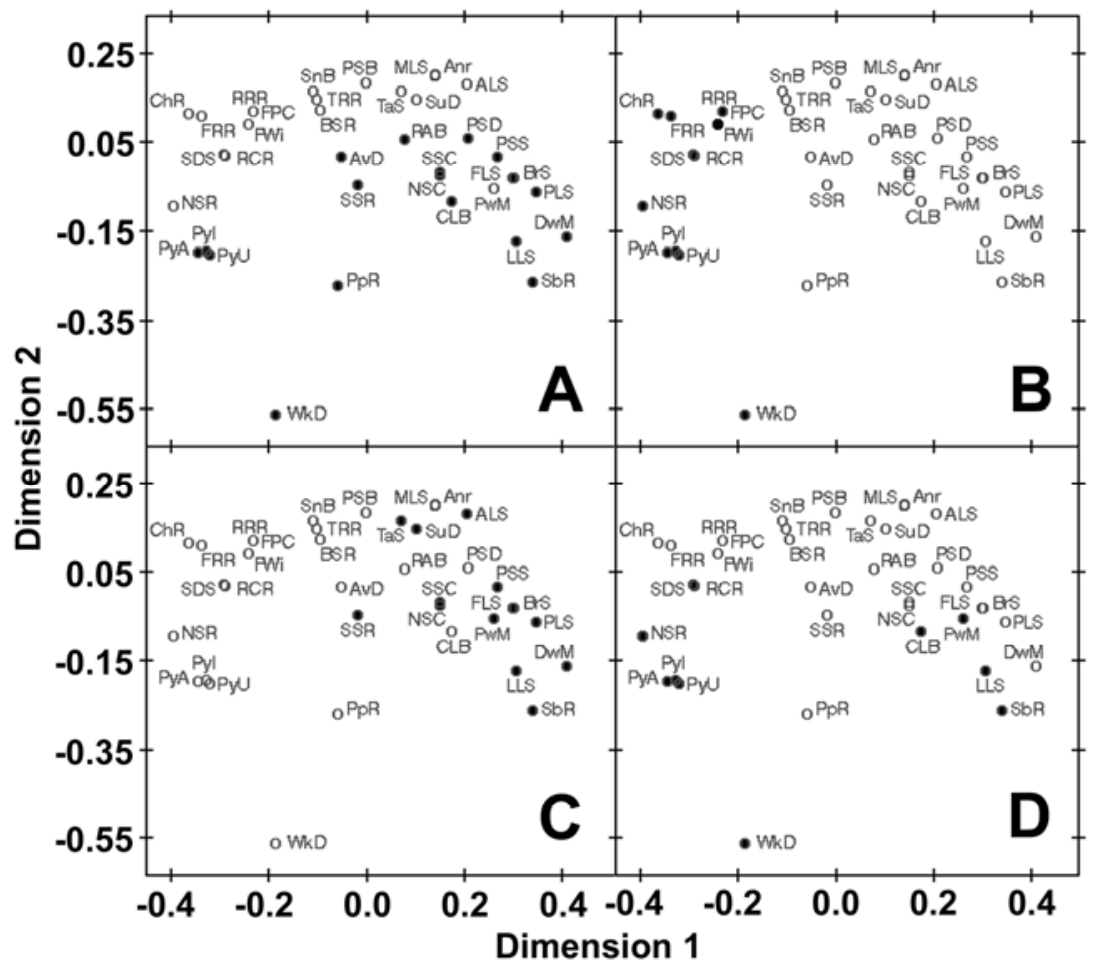

Fig. 2. Principal coordinate analysis projection of soybean diseases in a two-dimensional space based on Gower's general similarity coefficients. Solid circles represent patterns in association with four characteristics. Solid circles represent: A, diseases that need free moisture (FM) from rainfall or dew for completion of infection; $\mathbf{B}$, diseases that do not have secondary infections (SI) in a growing season; $\mathbf{C}$, diseases with pathogens that can be disseminated by wind (WD); and $\mathbf{D}$, diseases with pathogens that cannot be seed transmittable (ST).
Phytophthora rot $(\mathrm{PpR})$ was outside of all these clusters.

\section{DISCUSSION}

Information on the geographical distribution of a disease or pathogen and historical yield loss has been documented in the literature $(9,22,41,58,64-68,72)$. In Figure 5, the diseases that caused major soybean yield losses from 1996 to 2005 (averaged annual estimation data, 66) are highlighted. Most severe yield losses were from the diseases in Cluster B and the diseases around the virtual Average Disease and Super Diseases. In Cluster C (AU $P$ value at $86 \%$ ), where soybean rust merged with Cluster A, only brown spot (BwS) and frogeye leaf spot (FLS) caused moderate damage.

In this loose cluster, Leptosphaerulina leaf spot (LLS) had a limited geographical distribution range in Missouri and Maryland in soybean $(9,22)$ and in other hosts in Georgia (14,18). Downy mildew (DwM), brown spot (BrS), frogeye leaf spot (FLS), and purple seed stain (PSS) have been reported widely from the Gulf Coast to the northern United States $(9,22)$, implicating a large range and a high disease prevalence. Phyllosticta leaf spot (PLS) was distributed in most regions of the Soybean Belt, especially in the cool region (22). Powdery mildew (PwM), which was not grouped in this cluster but resembled soybean rust (similarity coefficient 0.792 ), has been reported in the southeastern and midwestern United States in states such as Georgia, Iowa, and Wisconsin (22). Among these diseases, Leptosphaerulina leaf spot had the most limited geographical distribution range, probably due to its low optimal temperature $\left(18^{\circ} \mathrm{C}\right)$ for disease development. The wide spread of downy mildew, brown spot, frogeye leaf spot, and purple seed stain were likely due to their moderate optimal temperatures for disease development $\left(21,25,26\right.$, and $27^{\circ} \mathrm{C}$, respectively) and capability of being seed transmittable. Phyllosticta leaf spot and powdery mildew had limited geographical distribution compared with the four most widely spread diseases. For Phyllosticta leaf spot, its narrow host range could be the reason. Powdery mildew is not seed transmittable, cannot survive on host residual or survive without a host, and has a cool optimal temperature for development $\left(20^{\circ} \mathrm{C}\right)$, which may have limited its distribution. On the other hand, it has a broad host range (ranked as 3) and does not require high moisture for infection, possibly compensating for the other disadvantages.

Compared with the four most widespread diseases mentioned above, soybean rust has an optimal disease development temperature of $26^{\circ} \mathrm{C}$ and a similar host range (ranked as 2), but it is not seed transmittable and cannot survive long-term without hosts or in plant residue. Synthesizing these characteristics, we expect that throughout the U.S. soybean production 
regions, soybean rust would have a maximum geographical distribution range similar to that of the four most widespread diseases, but a limited regional prevalence. Under certain weather conditions that strongly favor its wind dispersal, soybean rust may have the potential to reach north into states such as Minnesota or Wisconsin. However, even if it reaches these states, the yield losses would be minor according to the pattern of yield losses in Figure 5. In the southern United States, including its overwintering region and the adjacent regions, soybean rust would likely cause moderate yield losses when weather conditions are favorable. It must be noted that even though the diseases grouped with soybean rust did not cause severe yield losses, the genetic background of soybean varieties may have affected the yield losses caused by certain diseases. Caution must be used in the management of soybean rust because of the lack of resistance to this disease in commercial fields.

In Figure 5, the great damage caused by the diseases around Average Disease and Super Disease may have been due to their relatively balanced characteristics, which may lead to wide adaptability within the U.S. soybean production regions. Charcoal rot (ChR), Fusarium root rot (FRR), sudden death syndrome (SDS), and Phytophthora rot $(\mathrm{PpR})$ also cause severe damage to soybean. This was likely due to their survival capabilities in adverse environmental conditions and the fact that infections from these diseases could kill the whole plant. In principal coordinate analysis, Weak Disease did not closely resemble real diseases, which makes its absence in nature not surprising. Similarly, Phytophthora rot was located far away from other fungal diseases, although much closer than Weak Disease. Along with Pythium spp. and the downy mildew pathogen, Phytophthora sojae was in the class Oomycetes, which may be part of the reason that it was not like the others but still caused great yield reduction. However, why it was still unique compared with Pythium spp. and the downy mildew pathogen remains a perplexing question.

The application of Gower's general similarity coefficient and principal coordinate analysis in comparative epidemiology provided us with comprehensive and visualized disease profiles with quantified links among them. In the two-dimensional space of PCoA projection, striking patterns and significant differences among the clusters

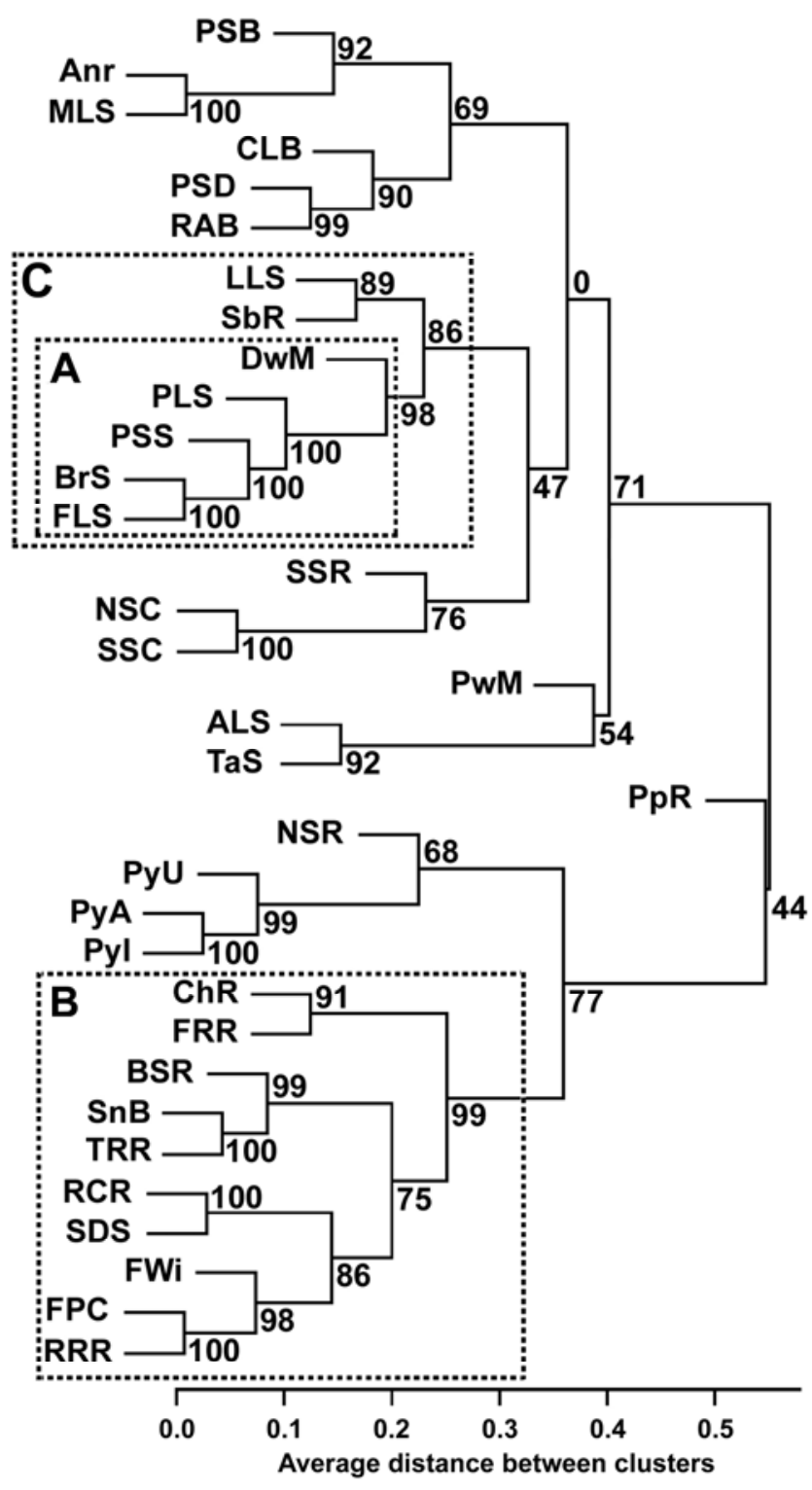

Fig. 3. A dendrogram illustrating grouped real soybean diseases by cluster analysis (UPGMA) based on the diseases' characteristics values in Table 1 and Gower's similarity coefficients. The number by each cluster indicated the estimated percent confidence level using multiscale bootstrapping. The total number of replications of the bootstrap resampling was 20,000 .

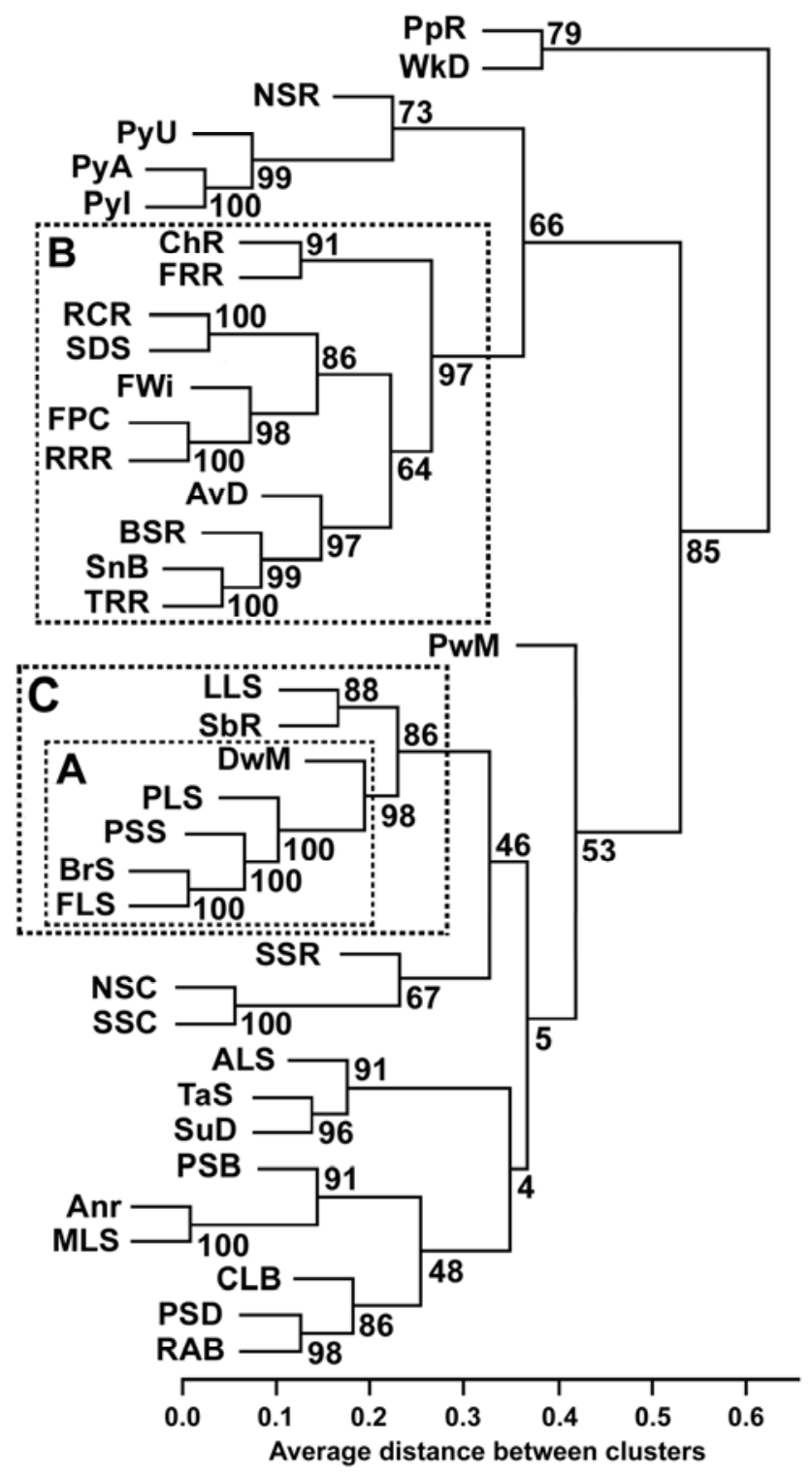

Fig. 4. Grouped soybean diseases including the three virtual diseases in a dendrogram by cluster analysis (UPGMA) based on the diseases' characteristics values in Table 1 and Gower's similarity coefficients. The number by each cluster indicated the estimated percent confidence level using multiscale bootstrapping. The total number of replications of the bootstrap resampling was 20,000 . 


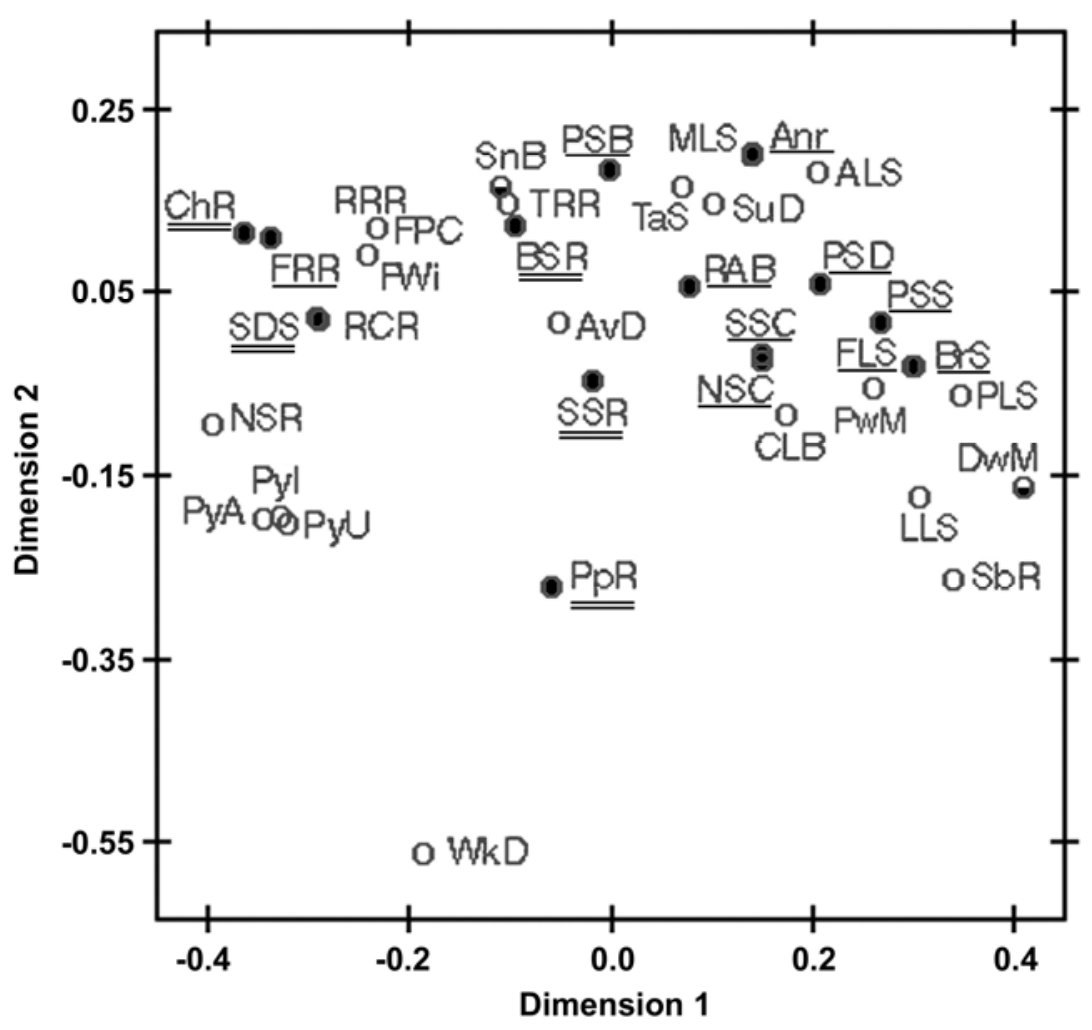

Fig. 5. Principal coordinate analysis projection of soybean diseases in a two-dimensional space based on Gower's general similarity coefficients. Solid circles represent diseases that caused significant yield losses based on averaged estimates of soybean yield losses in the United States from 1996 to 2005. The codes of those that caused severe yield damage (annual yield losses $>10^{7}$ bushels) were double underlined. Those that caused moderate yield damage (annual yield losses of $10^{6}$ to $10^{7}$ bushels) were single underlined. Soybean downy mildew (DwM) and southern blight (SnB) only caused minor yield losses $\left(<10^{6}\right.$ bushels) and were marked with half-closed circles.

of these diseases were identified other than in four-dimension temporal-spatial space. If we treat the PCoA projection in Figure 1 as a function and the environmental conditions in the U.S. soybean production regions as the input, then the pattern of yield loss data in Figure 5 can be treated as one of the outputs of this function. Of course, there are other outputs, e.g., the diseases' geographical distribution range patterns, for which we did not have detailed information in this study. These outputs would change in other soybean production regions such as China and South America due to different environmental conditions. Studies to compare all the soybean fungal diseases in these three regions would be worthy endeavors.

The soybean rust pathogen, $P$. pachyrhizi, has a life cycle different from other soybean fungal pathogens, although from what is known so far, its life cycle is relatively simple. Further study to compare soybean rust disease with other rust diseases, such as wheat leaf rust (Puccinia triticina) and corn common rust (Puccinia sorghi), for their geographical distribution and outbreak frequencies may shed light on this important topic.

\section{ACKNOWLEDGMENTS}

We thank the United Soybean Board and the National Natural Science Foundation of China (NSFC) for funding.

\section{LITERATURE CITED}

1. Abawi, G. S., and Grogan, R. G. 1975. Source of primary inoculum and effects of temperature and moisture on infection of beans by Whetzelinia sclerotiorum. Phytopathology 65:300-309.

2. Agarwal, D. K., Gangopadhyay, S., and Sarbhoy, A. K. 1973. Effect of temperature on the charcoal rot disease of soybean. Indian Phytopathol. 26:587-589.

3. Agrios, G. N. 1997. Plant Pathology. 4th ed. Academic Press, San Diego, CA.

4. Almeida, A. M. R., Saraiva, O. F., Farias, J. R. B., Gaudencio, C. A., and Torres, E. 2001. Survival of pathogens on soybean debris under no-tillage and conventional tillage systems. Pesquisa Agropecuaria Bras. 36:1231-1238.

5. Balducchi, A. J., and McGee, D. C. 1987. Environmental factors influencing infection of soybean seeds by Phomopsis and Diaporthe species during seed maturation. Plant Dis. 71:209-212.

6. Barbetti, M. J. 1991. Effects of temperature and humidity on diseases caused by Phoma medicaginis and Leptosphaerulina trifolii in lucerne (Medicago sativa). Plant Pathol. 40:296-301.

7. Beute, M. K., and Rodriguez-Kabana, R. 1981. Effects of soil moisture, temperature and field environment on survival of Sclerotium rolfsii in Alabama and North Carolina. Phytopathology 71:1293-1296.

8. Brown, J. H. 1995. Macroecology. University of Chicago Press, Chicago, IL.

9. CAB International [CABI]. 2008. Crop Protection Compendium. $\mathrm{CAB}$ International. Online publication.

10. Carris, L. M., Glawe, D. A., and Gray, L. E. 1986. Isolation of the soybean pathogens Corynespora cassiicola and Phialophora gre- gata from cysts of Heterodera glycines in Illinois. Mycologia 78:503-506.

11. Cheng, Y. H., and Schenck, N. C. 1978. Effect of soil temperature and moisture on survival of the soybean root rot fungi Neocosmospora vasinfecta and Fusarium solani in soil. Plant Dis. Rep. 62:945-949.

12. Davison, A. C., and Hinkley, D. V. 1997. Bootstrap Methods and Their Application. Cambridge University Press, Cambridge, UK.

13. Dorrance, A. E., Kleinhenz, M. D., McClure, S. A., and Tuttle, N. T. 2003. Temperature, moisture, and seed treatment effects on Rhizoctonia solani root rot of soybean. Plant Dis. 87:533-538.

14. Farr, D. F., Bills, G. F., Chamuris, G. P., and Rossman, A. Y. 1989. Fungi on Plants and Plant Products in the United States. American Phytopathological Society, St. Paul, MN.

15. Gaston, K. J. 2000. Global patterns in biodiversity. Nature 405:220-227

16. Gleason, M. L., and Ferriss, R. S. 1987. Effects of soil moisture and temperature on Phomopsis seed decay of soybean in relation to host and pathogen growth rates. Phytopathology 77:1152-1157.

17. Gower, J. C. 1971. A general coefficient of similarity and some of its properties. Biometrics 27:857-871.

18. Graham, J. H., and Luttrell, E. S. 1961. Species of Leptosphaerulina on forage plants. Phytopathology 51:680-693.

19. Graham, J. H., and Timmer, N. H. 1991. Peatbased media as a source of Thielaviopsis basicola causing black root rot on citrus seedlings. Plant Dis. 75:1246-1249.

20. Gupta, A. K., and Pathak, V. N. 1990. Epidemiology and management of papaya fruit rots. Sum. Phytopathol. 16:92-105.

21. Hanski, I., and Gyllenberg, M. 1997. Uniting two general patterns in the distribution of species. Science 275:397-400.

22. Hartman, G. L., Sinclair, J. B., and Rupe, J. C., eds. 1999. Compendium of Soybean Diseases. 4th ed. American Phytopathological Society, St. Paul, MN.

23. Hatzipapas, P., Kalosaka, K., Dara, A., and Christias, C. 2002. Spore germination and appressorium formation in the entomopathogenic Alternaria alternata. Mycol. Res. 106:13491359.

24. Kaufman, L., and Rousseeuw, P. J. 1990. Finding Groups in Data: An Introduction to Cluster Analysis. John Wiley \& Sons, Hoboken, NJ.

25. Kaushal, R. P., Anil, K., and Tyagi, P. D. 1998 Role of light, temperature and relative humidity on germination of Colletotrichum truncatum and soybean pod infection under laboratory conditions. J. Mycol. Plant Pathol. 28:1-4.

26. Keeling, B. L. 1988. Influence of temperature on growth and pathogenicity of geographic isolates of Diaporthe phaseolorum var. caulivora. Plant Dis. 72:220-222.

27. Khare, M. N., and Bhargava, P. K. 1999. Alternaria blight of chickpea - retrospect and prospects. Indian J. Pulses Res. 12:1-12.

28. Kmetz, K. T., Ellett, C. W., and Schmitthenner, A. F. 1979. Soybean seed decay: Sources of inoculum and nature of infection. Phytopathology 69:798-801

29. Kousik, C. S., Snow, J. P., Berggren, G. T., and Harville, B. G. 1995. Effect of temperature on virulence of Rhizoctonia solani on soybean leaves and seedlings. Plant Pathol. 44:580-586.

30. Kranz, J. 1974. Comparison of epidemics. Annu. Rev. Phytopathol. 12:355-374.

31. Kranz, J., ed. 1990. Epidemics of Plant Diseases. Springer-Verlag, New York.

32. Kranz, J. 2003. Comparative Epidemiology of Plant Diseases. Springer, New York.

33. Kuchler, F., Duffy, M., Shrum, R. D., and Dowler, W. M. 1984. Potential economic consequences of the entry of an exotic fungal pest: 
The case of soybean rust. Phytopathology 74:916-920.

34. Lakshminarayana, C. S., and Joshi, L. K. 1978. Myrothecium disease of soybean in India. Plant Dis. Rep. 62:231-234.

35. Lebeda, A., and Jendrulek, T. 1987. Application of cluster analysis for establishment of genetic similarity in gene-for-gene hostparasite relationships. J. Phytopathol. 119:131141.

36. Legendre, P., and Legendre, L. 1998. Numerical Ecology. 2nd ed. Elsevier Science B. V., Amsterdam, Netherlands.

37. Li, X., Engelbrecht, C. J., Mueller, D. S., and Yang, X. B. 2008. First report of soybean rust caused by Phakopsora pachyrhizi in Iowa and its statewide occurrence. Plant Dis. 92:975.

38. Liu, X. M., and Zhang, M. H. 1993. Influence of temperature and leaf wetness duration on infection of soybean frogeye leaf spot caused by Cercospora sojina. Acta Phytopathol. Sinica 23:321-325.

39. Lomolino, M. V., Riddle, B. R., and Brown, J. H. 2006. Biogeography. 3rd ed. Sinauer Associates, Inc., Sunderland, MA.

40. Massart, D. L., and Kaufman, L. 1983. The Interpretation of Analytical Chemical Data by the Use of Cluster Analysis. John Wiley \& Sons, New York.

41. McGee, D. C., ed. 1992. Soybean Diseases: A Reference Source for Seed Technologists. American Phytopathological Society, St. Paul, MN.

42. Meyer, W. A., Sinclair, J. B., and Khare, M. N. 1974. Factors affecting charcoal rot of soybean seedlings. Phytopathology 64:845-849.

43. Nelson, P. E. 1981. Life cycle and epidemiology of Fusarium oxysporum. Pages 51-80 in: Fungal Wilt Diseases of Plants. M. E. Mace, A. A. Bell, and C. H. Beckman, eds. Academic Press, New York.

44. Phillips, D. V. 1971. A disease of soybean caused by Neocosmospora vasinfecta. Phytopathology 61:906.

45. Pivonia, S., and Yang, X. B. 2004. Assessment of the potential year-round establishment of soybean rust throughout the world. Plant Dis. 88:523-529.

46. Pivonia, S., and Yang, X. B. 2006. Relating epidemic progress from a general disease model to seasonal appearance time of rusts in the United States: Implications for soybean rust. Phytopathology 96:400-407.

47. Ploetz, R. C., and Shokes, F. M. 1987. Factors influencing infection of soybean seedlings by southern Diaporthe phaseolorum. Phytopa- thology 77:786-790.

48. Poon, E. S., Leu, L. S., Liu, C., and Cheng, W. T. 1982. Pathogeographic studies of sugarcane downy mildew in Taiwan I. Historical analysis, regional pathogeographic classification and some considerations of disease attributes of the epidemics. Ann. Phytopathol. Soc. Jpn. 48:153-161.

49. Punja, Z. K. 1985. The biology, ecology, and control of Sclerotium rolfsii. Annu. Rev. Phytopathol. 23:97-127.

50. Rapoport, E. H. 1982. Aerography: Geographical Strategies of Species. Pergamon Press, Oxford, UK.

51. Sache, I., and De Vallavieille-Pope, C. 1995. Classification of airborne plant pathogens based on sporulation and infection characteristics. Can. J. Bot. 73:1186-1195.

52. Sahu, K. C., and Narain, A. 1995. Viability of sclerotia of Sclerotium rolfsii in soil at different temperature and moisture levels. Environ. Ecol. 13:300-303.

53. Scherm, H., and Yang, X. B. 1996. Development of sudden death syndrome of soybean in relation to soil temperature and soil water matric potential. Phytopathology 86:642-649.

54. Schlub, R. L., and Lockwood, J. L. 1981. Etiology and epidemiology of seedling rot of soybean by Pythium ultimum. Phytopathology 71:134-138.

55. Schneider, R. W., Hollier, C. A., Whitam, H. K., Palm, M. E., McKemy, J. M., Hernandez, J. R., Levy, L., and De Vries-Paterson, R. 2005. First report of soybean rust caused by Phakopsora pachyrhizi in the continental United States. Plant Dis. 89:774.

56. Schuh, W. 1992. Effect of pod development stage, temperature, and pod wetness duration on the incidence of purple seed stain of soybeans. Phytopathology 82:446-451.

57. Shimodaira, H. 2004. Approximately unbiased tests of regions using multistep-multiscale bootstrap resampling. Ann. Stat. 32:26162641

58. Sinclair, J. B., and Dhingra, O. D. 1975. An Annotated Bibliography of Soybean Diseases 1882-1974. International Soybean Program, Urbana, IL.

59. Singh, R., Singh, S. B., and Singh, P. N. 2001. Effect of environmental conditions on development of anthracnose of soybean. Ann. Plant Prot. Sci. 9:146-147.

60. Sneh, B., Jabaji-Hare, S., Neate, S., and Dijst, G., eds. 1996. Rhizoctonia species: Taxonomy, Molecular Biology, Ecology, Pathology and Control. Kluwer Academic, London, UK.
61. Suzuki, R., and Shimodaira, H. 2006. Pvclust: An $R$ package for assessing the uncertainty in hierarchical clustering. Bioinformatics 22:1540-1542.

62. TeKrony, D. M., Egli, D. B., Stuckey, R. E., and Balles, J. 1983. Relationship between weather and soybean seed infection by Phomopsis sp. Phytopathology 73:914-918.

63. Vidic, M., and Jasnic, S. 1988. Contribution to the study of the epidemiology of Diaporthe phaseolorum var. caulivora on soyabean. Zastita Bilja 39:297-310.

64. Wrather, J. A., Anderson, T. R., Arsyad, D. M., Gai, J., Ploper, L. D., Porta-Puglia, A., Ram, H. H., and Yorinori, J. T. 1997. Soybean disease loss estimates for the top 10 soybean producing countries in 1994. Plant Dis. 81:107110 .

65. Wrather, J. A., Chambers, A. Y., Fox, J. A., Moore, W. F., and Sciumbato, G. L. 1995 Soybean disease loss estimates for the southern United States, 1974 to 1994. Plant Dis. 79:1076-1079.

66. Wrather, J. A., and Koenning, S. 2005. Soybean disease loss estimates for the United States, 1996-2005. Missouri Agricultural Experiment Station, Delta Research Center. Online publication.

67. Wrather, J. A., Stienstra, W. C., and Koenning, S. R. 2001. Soybean disease loss estimates for the United States from 1996 to 1998. Can. J. Plant Pathol. 23:122-131.

68. Wyllie, T. D., and Scott, D. H., eds. 1988 Soybean Diseases of the North Central Region. American Phytopathology Society, St. Paul, MN.

69. Yang, Q. K., Ma, Z. F., and Li, J. W. 1994 Problems and solutions for soyabeans following soyabeans or soyabeans following soyabeans separated by another crop in Heilongjiang. Soybean Sci. 13:157-163.

70. Yang, X. B. 2006. Framework development in plant disease risk assessment and its application. Eur. J. Plant Pathol. 11(5):25-34.

71. Yang, X. B., Dowler, W. M., and Royer, M. H. 1991. Assessing the risk and potential impact of an exotic plant disease. Plant Dis. 75:976 982.

72. Yang, X. B., and Feng, F. 2001. Ranges and diversity of soybean fungal diseases in North America. Phytopathology 91:769-775.

73. Yang, X. B., and Scherm, H. 1997. El Nino and infectious disease. Science 275:739.

74. Yang, X. B., and Zeng, S. M. 1992. Detecting patterns of wheat stripe rust pandemics in time and space. Phytopathology 82:571-576. 